\title{
Native understory palms (Arecaceae) of the Atlantic Forest in Santa Catarina, Southern Brazil
}

\author{
Guilherme Alves Elias ${ }^{1,4}$, André Luís de Gasper ${ }^{2}$, Joanna Marie Tucker Lima ${ }^{3}$, Guilherme Lodetti ${ }^{1}$ \\ \& Robson dos Santos ${ }^{1}$
}

\begin{abstract}
In this study, we examined the distribution and conservation status of understory palms in the Brazilian state of Santa Catarina using data collected by the Floristic and Forest Inventory of Santa Catarina (IFFSC). Understory palms were systematically sampled within sampling units (SU) distributed over a state-wide 10 $\times 10 \mathrm{~km}$ grid. Among the 206 total SU monitored by IFFSC within Pluvial and Coastal Forest, $86 \%$ ( $\mathrm{n}=177$ SU) contained understory palms, comprising 1738 individuals from the following species: Bactris setosa, Geonoma elegans, G. gamiova, and G. schottiana. To explore the conservation status of understory palm populations in Santa Catarina, we overlaid a map of federal priority conservation areas on top of IFFSC distribution data for understory palms. Conservation priority levels defined by the Brazilian Environmental Agency (MMA) are rated Extremely High, Very High, High and Insufficiently Known. Ninety-four percent of the SU containing understory palms overlapped priority conservation areas, highlighting the centrality of understory palms in biodiversity conservation. Despite the wide distribution of understory palm communities in Santa Catarina, intense scrutiny of forest remnants is necessary in view of sensitivity to environmental disturbance, so as to guarantee the maintenance of understory palm populations and their ecosystem services. Key words: biodiversity, Conservation Units, floristic and forest inventory of Santa Catarina, threatened species, Palmae, priority conservation areas.
\end{abstract}

\section{Resumo}

Neste estudo foram analisadas a distribuição e o status de conservação das palmeiras arbustivas no estado brasileiro de Santa Catarina utilizando os dados coletados pelo Inventário Florístico Florestal de Santa Catarina (IFFSC). As palmeiras arbustivas foram amostradas sistematicamente em Unidades Amostrais (UA) distribuídas sobre o estado em parcelas de $10 \times 10 \mathrm{~km}$. Dentre todas as 206 UA levantadas pelo IFFSC na Floresta Pluvial e Litorânea, $86 \%$ ( $\mathrm{n}=177 \mathrm{UA}$ ) tiveram a presença de palmeiras arbustivas, totalizando 1738 indivíduos das seguintes espécies: Bactris setosa, Geonoma elegans, G. gamiova e G. schottiana. Para investigar o status de conservação das palmeiras arbustivas de Santa Catarina foi sobreposto o mapa das áreas prioritárias para conservação com os dados de distribuição das palmeiras arbustivas coletados pelas equipes do IFFSC. Os níveis de prioridade de conservação definidos pelo Ministério do Meio Ambiente (MMA) foram classificados como Extremamente Alto, Muito Alto, Alto e Insuficientemente Conhecido. Noventa e quatro por cento das UA contendo palmeiras arbustivas sobrepuseram áreas prioritárias para conservação, destacando a importância das palmeiras arbustivas na conservação da biodiversidade. Apesar da ampla distribuição das comunidades de palmeiras arbustivas em Santa Catarina, são necessárias pesquisas minuciosas nos remanescentes florestais tendo em vista a sensibilidade à perturbação ambiental, de forma a garantir a manutenção das populações de palmeiras arbustivas e seus serviços ecossistêmicos.

Palavras-chave: biodiversidade, Unidades de Conservação, inventário florístico florestal de Santa Catarina, espécies ameaçadas, Palmae, áreas prioritárias para conservação.

\footnotetext{
${ }^{1}$ Universidade do Extremo Sul Catarinense, Herbário Pe. Dr. Raulino Reitz (CRI), Av. Universitária 1105, 88806-000, Criciúma, SC, Brasil.

${ }^{2}$ Universidade Regional de Blumenau, Herbário Dr. Roberto Miguel Klein (FURB), R. Antônio da Veiga 140, 89012-900, Blumenau, SC, Brasil.

${ }^{3}$ Montgomery Botanical Center, 11901 Old Cutler Rd, Coral Gables, FL, 33156-4242, USA.

${ }^{4}$ Author for correspondence: guilherme@unesc.net
} 


\section{Introduction}

Palms belong to one of the largest plant families and represent a key component of both the forest canopy and understory plant communities (Reitz 1974; Kahn \& Mejia 1990; Kahn \& Granville 1992; Henderson 2002; Soares et al. 2014; Elias et al. 2016). They also play a critical role in the diet of several animal groups, as much for frugivores as for pollinators (Scariot 2015), and are considered a key resource in times of food scarcity (Zona \& Henderson 1989; Andreazzi et al. 2009; Genini et al. 2009; Soares et al. 2014). Furthermore, palms are vital to the subsistence of many traditional and rural communities, providing a wide range of nontimber forest products, as for example food and medicinal uses from fruits, cosmetics, fiber used from leaves, building materials from leaves and stems, and handicraft from seeds (Scariot 2015; Elias \& Santos 2016).

Shrubby palms characterize the understory of certain vegetation formations in Santa Catarina, such as the Pluvial Broadleaved Forest and Coastal Broadleaved Forest, sometimes forming dense clusters (Reitz 1974). These species include Bactris setosa Mart., Geonoma elegans Mart., G. gamiova Barb.Rodr. e G. schottiana Mart. Other palm species native to Santa Catarina, considered large arborescent palms include Astrocaryum aculeatissimum (Schott) Burret, Attalea dubia (Mart.) Burret, Butia catarinensis Noblick \& Lorenzi, B. eriospatha (Mart. ex Drude) Becc., Euterpe edulis Mart., Syagrus romanzoffiana (Cham.) Glassman e Trithrinax acanthocoma Drude (Elias et al. 2016).

The state of Santa Catarina has been a pioneer in the study of its forests and flora, exemplified by the Illustrated Flora of Santa Catarina, one of the most comprehensive works on Brazilian plants, developed by Reitz (1965), and the Barbosa Rodrigues Herbarium (HBR). And, currently, the Floristic and Forest Inventory of Santa Catarina (IFFSC) (Vibrans et al. 2012a,b; Vibrans et al. 2013b,c,d), which disseminates current comprehensive data on Santa Catarina forest flora. The latter represents a valuable dataset for the study of understory palms. One of IFFSC's goals was to evaluate the quality and extent of Santa Catarina's forest remnants (Gasper et al. 2011). It also assesses the conservation status of forest remnants and informs public policies regarding land use and the conservation of natural resources in Santa Catarina (Vibrans et al. 2013 b).
On May 21, 2004, in an effort to advance the conservation of the Atlantic Forest, which extends across the entire state of Santa Catarina, the Brazilian National Ministry of the Environment delineated three categories of conservation areas in the state: (1) conservation, (2) sustainable use and (3) sharing the benefits of biodiversity (Decree No. 5092). Brazil's Federal Ordinance No. 126 (May 27, 2004) mandated the mapping of these conservation areas, which includes supplementary material with policy recommendations and assigns priority levels to each conservation unit.

Within this context, we applied IFFSC data to describe understory palm (Arecaceae) communities in Santa Catarina and expand our knowledge about this ecologically and economically important plant family in southern Brazil, summarizing their distribution in the state and pinpointing priority areas for conservation.

\section{Material and Methods}

Understory palms were sampled as part of the IFFSC in areas of Pluvial and Coastal Forest in Santa Catarina. Rainfall is well distributed throughout the state with an annual average of 1250-2000 mm/yr, with no areas of regular drought (Nimer 1990). The Köppen climate classification for Santa Catarina is humid subtropical with no defined dry season and hot summers (Cfa), or balmy summers ( $\mathrm{Cfb}$ ), corresponding to $40 \%$ and $60 \%$ of the study area, respectively (Alvares et al. 2013).

The sampling consisted of units (SU) systematically distributed over a state-wide $10 \times$ $10 \mathrm{~km}$ grid, resulting in $202 \mathrm{SU}$ in Pluvial Forest and four in Coastal Forest. Each SU is made up of four $1000 \mathrm{~m}^{2}$ subplots $(20 \times 50 \mathrm{~m})$ positioned in the four cardinal directions, each SU covered a total area of 82.4 ha (Fig. 1; see Vibrans et al. 2010 for more details on sample design and methods). One SU was installed wherever the sampling grid intersected a forested area or fragment $\geq 10$ ha.

To shed light on the conservation status of understory palm populations in Santa Catarina, we intersected a map of priority conservation areas, available on the MMA website (MMA 2007), with IFFSC data on understory palm distributions, using the software ArcGIS 10.2.2. Conservation priority levels defined by MMA include Extremely High, Very High, High and Insufficiently Known. 


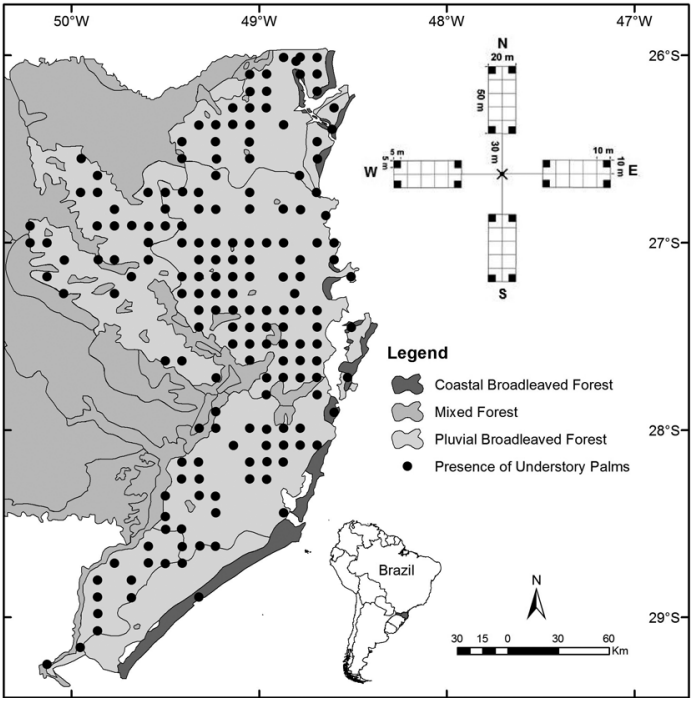

Figure 1 - Locations Floristic and Forest Inventory of Santa Catarina (IFFSC) Sampling Units (SU) with presence of understory palms, according to Klein's vegetation map (1978).

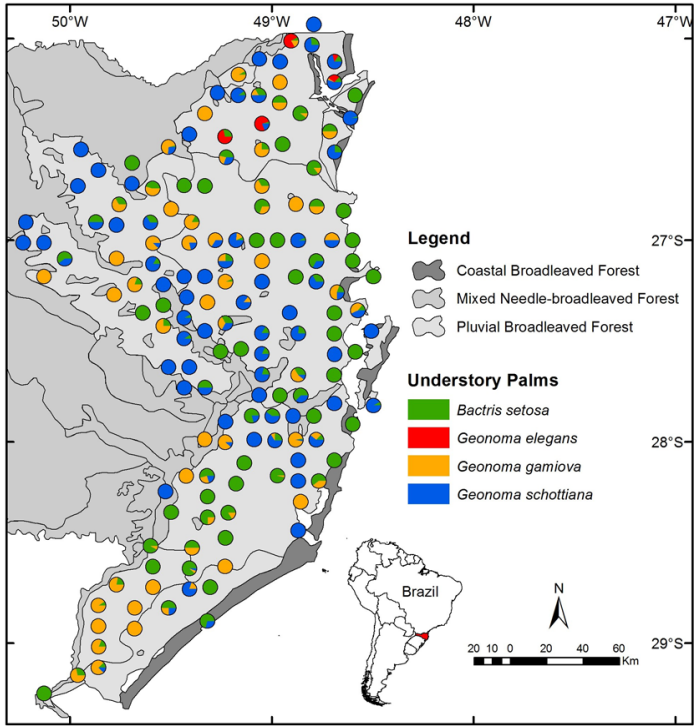

Figure 2 - Species distribution of understory palms registered by the Floristic and Forest Inventory of Santa Catarina (IFFSC).

Table 1 - Understory palms species registered by the Floristic and Forest Inventory of Santa Catarina.

\begin{tabular}{lccc}
\hline \multicolumn{1}{c}{ Species } & Individuals & SU & H (m) \\
\hline Bactris setosa & 480 & 101 & $0.5-7.0$ \\
Geonoma elegans & 56 & 5 & $0.6-2.5$ \\
Geonoma gamiova & 439 & 67 & $0.5-5.0$ \\
Geonoma schottiana & 763 & 83 & $0.5-8.0$ \\
\hline
\end{tabular}

Individuals: Total number of individuals; SU: Sampling Units where the species occurred $\left(4,000 \mathrm{~m}^{2}\right) ; \mathrm{H}(\mathrm{m})$ : Height range, in meters.

\section{Results}

Among the 206 SU monitored by IFFSC within Pluvial and Coastal Forest, 86\% ( $\mathrm{n}=177$ SU) contained understory palms, totaling 1738 individuals from the following species: Bactris setosa, Geonoma elegans, G. gamiova e G. schottiana (Fig. 2).

Geonoma elegans exhibited the lowest abundance of any understory palm species in Santa Catarina ( $\mathrm{n}=5$; Tab. 1), and all individuals occurred in the northern part of the state. On the other hand, Bactris setosa was the most widely distributed species in this study, present in $60 \%$ of all SU, followed by Geonoma schottiana (47\%), G. gamiova (38\%) and G. elegans (3\%).
With respect to priority areas for biodiversity conservation in Santa Catarina, 166 of the 177 SU (94\%) with understory palms fell within conservation areas (Fig. 3). One hundred and four SU containing understory palms (62\%) intersected areas ranked as Very High Priority, $51 \mathrm{SU}(31 \%)$ as Extremely High, $10 \mathrm{SU}(6 \%)$ corresponded with High Priority areas and $1 \mathrm{SU}$ as Insufficiently Known (1\%). Only 11 SU (6\%) had no overlap with biodiversity conservation priority areas, and no palms were recorded in areas delineated as Very High Priority or Insufficiently Known (Fig. 3).

\section{Discussion}

Bactris setosa, G. gamiova and G. schottiana were randomly distributed throughout the Pluvial 


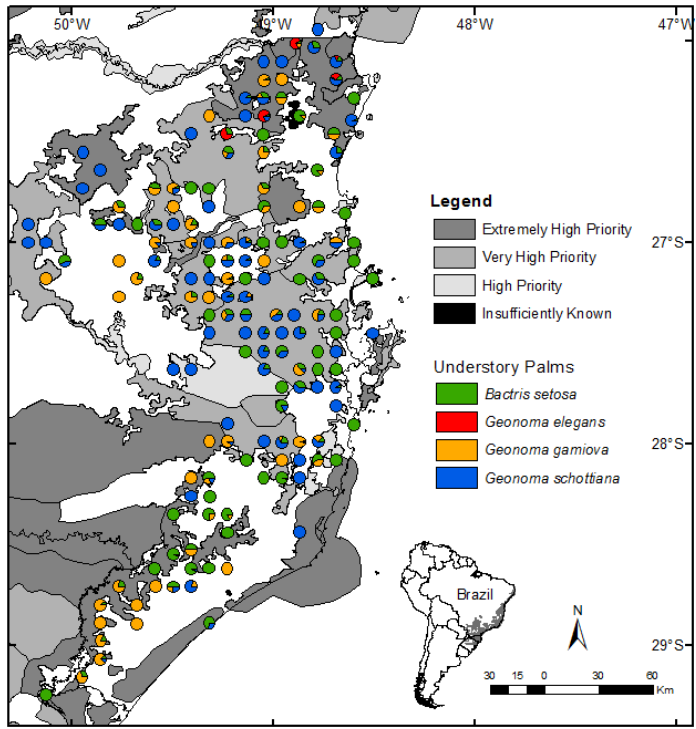

Figure 3 - Overlap of understory palm communities with biodiversity conservation priority areas in Santa Catarina, Brazil (MMA 2007). NOTE: white regions on the map represent urbanized areas that were not evaluated for biodiversity conservation.

Forest, supporting Reitz's (1974) findings that these species dominate the forest understory, where they exhibit a consistent association with less-altered, shady environments. The same author highlighted the occurrence of these species at higher altitudes, which we also observed with some populations extending into Mixed Forest areas (high altitude).

Only four SU (Vibrans et al. 2010) were installed within Coastal Forest due to the scarcity of forest remnants in this vegetation zone. Environmental degradation from human activities common to these forests has converted much of this area to cattle pastures and old paths. (Perovano \& Lima 2003; Vibrans et al. 2013c). Understory palms (B. setosa and G. schottiana) were found in two Coastal Forest SU, but in small numbers (i.e., only three individuals). The scarcity of palm species in Coastal Forest not only reflects their poor adaptability to disturbed environments (Ferreira 2010) but also their intolerance for temporarily waterlogged soils (Reitz 1974), marked features of this forest type observed by IFFSC's diagnostics team.

The low frequency and density of G. elegans is attributed to vulnerability to disturbance and, perhaps even more so, to edaphic factors (Lorenzi 2010) that mediate G. elegans survival. This species responds negatively to sudden changes in soil drainage and prefers shady, wet locations, characteristic of the five SU where these understory palms were recorded (Vibrans et al. 2013b). Santa Catarina is considered the southern limit for this species (Reitz 1974).

The dominance of $B$. setosa reflects the successful establishment of the Bactris genus (Monteiro \& Fish 2005) throughout Santa Catarina's forests, in addition to a preference for moist sites (Reitz 1974), where these palms tend to grow into dense, robust clusters (Lima \& Soares 2003). Reitz (1974) also observed an extensive, though discontinuous, distribution of $B$. setosa in Santa Catarina. Still, B. setosa is typically associated with forested environments with low levels of disturbance (Soares et al. 2014).

Species from the genus Geonoma exhibit less adaptability compared to Bactris, rarely occurring in open vegetation, and demonstrating higher vulnerability to disturbance, which tends to precipitate the disappearance of Geonoma palm populations (Henderson et al. 1995; Lorenzi 2010). Geonoma schottiana is adapted to very humid environments, preferring temporarily soaked soils along slopes (between 250-500 m altitude), where they dominate the forest understory (Reitz 1974). On the other hand, G. gamiova shows no specific soil preference and grows in various habitats, ranging from floodplains to upper slopes, but it does require less altered environments for its survival (Reitz 1974). This species occurs at high frequencies in the states of Paraná and Santa Catarina (Lorenzi 2010).

The large number of $G$. schottiana and $B$. setosa palms corroborates Reitz's (1974) work, which revealed high understory densities of these species. Height intervals (Tab. 1) measured by IFFSC team also corroborate other taxonomic studies conducted in the Atlantic Forest (Soares et al. 2014; Caxambú et al. 2015) and Santa Catarina (Reitz 1974).

\section{Priority Areas for Biodiversity Conservation}

The elevated number of SU overlapping priority conservation areas highlights the importance of the IFFSC as a tool for proper forest management and conservation (Vibrans et al. 2013b).

The substantial overlap of understory palms with priority biodiversity conservation areas in the Pluvial and Coastal Forests of Santa Catarina calls attention to the fragility of these environments, 
which despite having the greatest forest cover in the state (Vibrans et al. 2013a), suffer from intense fragmentation and the relentless advance of the agricultural and urban frontiers (Wright \& MullerLandau 2006).

For Extremely High Priority, Very High Priority and High Priority conservation areas, the Brazilian Ministry of the Environment recommends the creation of conservation units that protect species continuity, especially species threatened with extinction or vulnerable to (MMA 2007), such as understory palms.

Currently, the state of Santa Catarina has ten fully protected conservation units (FATMA 2016), seven of which are located in areas included in this study. Altogether these conservation units protect an area of 118,549 ha, corresponding to $1.24 \%$ of Santa Catarina (FATMA 2016). This value is negligible, however, considering that the total remaining forest in Santa Catarina covers approximately $29 \%$ of the state (Vibrans et al. 2013b). Therefore, the formulation of public policies for the creation of new conservation units in Santa Catarina is critical to ensuring the longterm conservation of the state's forests.

A lack of fully protected conservation units in the northern part of the state raises concern, especially for G. elegans populations that are at risk of disappearing from the state due to their narrow habitat requirements. Moreover, the ecology of this species has yet to be comprehensively studied (Elias et al. 2015).

Bactris setosa, G. gamiova e G. schottiana reflect a more hopeful scenario with regard to their distribution, since they occur across a greater number of SU and at higher densities; however, due to the ever-increasing intensity of human activities that modify the landscape, these communities remain susceptible to reductions in population size (Tabarelli et al. 2010). The potential for biodiversity loss in Santa Catarina's forest remnants is particularly worrisome, considering that one-fifth of the forest species found during 1950 and 1970 floristic expeditions to the state by the botanists Pe. Dr. Raulino Reitz and Dr. Roberto Miguel Klein were no longer observed in 2010 (Vibrans et al. 2013b).

Despite the current wide distribution of understory palm communities in Santa Catarina, intense scrutiny of forest remnants is necessary in view of their sensitivity to environmental disturbance in order to maintain the biodiversity of understory palm populations and their ecosystem services, including food and shelter for wildlife and non-timber forest products.

\section{Referências}

Alvares CA, Stape JL, Sentelhas PC, Gonçalves JLM \& Sparovek G (2013) Köppen's climate classification map for Brazil. Meteorologische Zeitschrift 22: 711-728.

Andreazzi CS, Pires AS \& Fernandez FAS (2009) Mamíferos e palmeiras neotropicais: interações em paisagens fragmentadas. Oecologia brasiliensis 13: 554-574.

Brasil - Decreto 5.092, de 21 de maio de 2004. Define regras para identificação de áreas prioritárias para a conservação, utilização Sustentável e repartição dos benefícios da biodiversidade, no âmbito das atribuições do Ministério do Meio Ambiente. Disponível em $<$ http:// http://www.mma.gov.br/estruturas/chm/ arquivos/dec5092.pdf $>$. Acesso em 15 março 2016.

Brasil - Portaria 126, de 27 de maio de 2004. Dispõe sobre o reconhecimento das áreas prioritárias para conservação, utilização sustentável e repartição dos benefícios da biodiversidade brasileira. Disponível em <http://www.mma.gov.br/estruturas/chm/ arquivos/port126.pdf $>$ Acesso em 15 março 2016.

Caxambú MG, Geraldino HCL, Dettke GA, Silva AR \& Santos EN (2015) Palmeiras (Arecaceae) nativas no município de Campo Mourão, Paraná, Brasil. Rodriguésia 66: 259-270.

Elias GA, Corrêa PF, Citadini-Zanette V \& Santos R (2015) Arecaceae: análise bibliométrica das espécies nativas do estado de Santa Catarina, Brasil. Ciência \& Natura 37: 85-92.

Elias GA \& Santos R (2016) Produtos florestais não madeireiros e valor potencial de exploração sustentável da Floresta Atlântica no sul de Santa Catarina. Ciência Florestal 26:249-262.

Elias GA, Gasper AL, Lima JMT, Soares KP, Molz M \& Santos R (2016) Community Structure of Large Native Arborescent Palms (Arecaceae) using data from the Floristic and Forest Inventory of Santa Catarina, Brazil. Australian Journal of Basic and Applied Sciences 10: 156-163.

FATMA - Fundação do Meio Ambiente (2016) Unidades de Conservação. Disponível em $<$ http://www.fatma. sc.gov.br/conteudo/unidades-de-conservacao>. Acesso em 22 março 2016.

Ferreira E (2010) Bactris. In: Lorenzi H, Noblick LR, Kahn F \& Ferreira E (2010) Flora brasileira: Arecaceae (Palmeiras). Instituto Plantarum, Nova Odessa. Pp. 104-156.

Gasper AL, Sevegnani L, Vibrans AC, Uhlmann A, Lingner DV, Verdi M, Dreveck S, Stival-Santos A, Brogni E, Schmitt R \& Klemz G (2011) Inventário de Dicksonia sellowiana Hook. em Santa Catarina. Acta Botânica Brasílica 25: 776-784. 
Genini J, Galetti M \& Morellato PC (2009) Fruiting phenology of palms and trees in an Atlantic rainforest land-bridge island. Flora 204: 131-145.

Henderson A, Galeano G \& Bernal R (1995) Field guide to the Palms of the Americas. Princeton University Press, Princeton. 363p.

Henderson A (2002) Evolution and ecology of palms. The New York Botanical Garden Press, New York. 259p.

Kahn F \& Granville JJ (1992) Palms in forest ecosystems of Amazonian. Ecological Series 95. Springer Verlag, Berlin. 226p.

Kahn F \& Mejia K (1990) Palm communities in wetland forest ecosystems of Peruvian Amazonia. Forest Ecology and Management 33: 169-179.

Klein RM (1978) Mapa fitogeográfico de Santa Catarina. Herbário Barbosa Rodrigues, Itajaí. 24p.

Lima AL \& Soares JJ (2003) Aspectos florísticos e ecológicos de palmeiras (Arecaceae) da Reserva Biológica de Duas Bocas, Cariacica, Espírito Santo. Boletim do Museu de Biologia Mello Leitão 16: 5-20.

Lorenzi H (2010) Geonoma. In: Lorenzi H, Noblick LR, Kahn F \& Ferreira E (eds.) Flora brasileira: Arecaceae (Palmeiras). Instituto Plantarum, Nova Odessa. Pp. 214-255.

MMA - Ministério do Meio Ambiente (2007) Áreas prioritárias. Disponível em <http://goo.gl/ PCvTuN>. Acesso em 22 março 2016.

Monteiro E \& Fisch S (2005) Estrutura e padrão espacial das populações de Bactris setosa Mart. E B. hatschbachii Noblick ex A. Hend (Arecaceae) em um gradiente altitudinal, Ubatuba (SP). Biota Neotropica 5: 1-7.

Nimer E (1990) Climatologia da região sul. In: Nimer E (ed.) Climatologia do Brasil. IBGE/Departamento de Recursos Naturais e Estudos Ambientais, Rio de Janeiro. Pp. 3-65.

Perovano TL \& Lima RN (2003) Dinâmica de ocupação do solo na faixa de Reserva Ecológica de Vila Velha (ES). Natureza Online 1: 17-23.

Reitz R (1965) Plano de coleção. In: Reitz R (ed.) Flora ilustrada catarinense. part. 4. Herbário Barbosa Rodrigues, Itajaí. Pp. 1-71.

Reitz R (1974) Palmeiras. In: Reitz R (ed.) Flora ilustrada catarinense. part. 1. Herbário Barbosa Rodrigues, Itajaí. Pp. 1-189.

Scariot AO (2015) Palmeiras brasileiras: botânica, ecologia, usos e conservação. In: Lopes R, Oliveira
MSP, Cavallari MM, Barbieri RL \& Conceição LDHCS (eds.) Palmeiras nativas do Brasil. Embrapa, Brasília. Pp. 15-33.

Soares KP, Longhi SJ, Neto LP \& Assis LC (2014) Palmeiras (Arecaceae) no Rio Grande do Sul, Brasil. Rodriguésia 65: 113-139.

Tabarelli M, Aguiar AV, Ribeiro MC, Metzger JP \& Peres CA (2010) Prospects for biodiversity conservation in the Atlantic Forest: Lessons from aging humanmodified landscapes. Biological Conservation 143: 2328-2340.

Vibrans AC, Sevegnani L, Lingner DV, Gasper AL \& Sabbagh S (2010) Inventário florístico florestal de Santa Catarina (IFFSC): aspectos metodológicos e operacionais. Pesquisa Florestal Brasileira 30: 291-302.

Vibrans AC, Sevegnani L, Gasper AL \& Lingner DV (2012a) Inventário florístico florestal de Santa Catarina: diversidade e conservação dos remanescentes florestais. Edifurb, Blumenau. 344p.

Vibrans AC, Sevegnani L, Gasper AL \& Lingner DV (2012b) Inventário florístico florestal de Santa Catarina: Floresta Estacional Decidual. Edifurb, Blumenau. 336p.

Vibrans AC, McRoberts RE, Moser P \& Nicoletti AL (2013a) Using satellite image-based maps and ground inventory data to estimate the area of the remaining Atlantic forest in the Brazilian state of Santa Catarina. Remote Sensing of Environment. 130: 87-95.

Vibrans AC, Sevegnani L, Gasper AL, Müller JJV \& Reis MS (2013b) Inventário florístico florestal de Santa Catarina: resultados resumidos. Edifurb, Blumenau. 37p.

Vibrans AC, Sevegnani L, Gasper AL \& Lingner DV (2013c) Inventário florístico florestal de Santa Catarina: Floresta Ombrófila Mista. Edifurb Blumenau. 440p.

Vibrans AC, Sevegnani L, Gasper AL \& Lingner DV (2013d) Inventário florístico florestal de Santa Catarina: Floresta Ombrófila Densa. Edifurb, Blumenau. 576p.

Wright SJ \& Muller-Landau HC (2006) The uncertain future of Tropical Forest species. Biotropica 38: 443-445.

Zona S \& Henderson A (1989) A review of animalmediated seed dispersal of palms. Selbyana 11: 6-21. 